\title{
FACTORS INFLUENCING INDIVIDUALS’ DECISION-MAKING AND CAUSING FINANCIAL CRISIS
}

\author{
Daiva JUREVIČIENE் ${ }^{\circledR}$, Viktorija SKVARCIANY (D*, \\ Austė LAGUNAVIČIŪTĖ D \\ Department of Economics Engineering, Faculty of Business Management, \\ Vilnius Gediminas Technical University, Vilnius, Lithuania \\ Received 11 April 2020; accepted 22 May 2020
}

\begin{abstract}
It is essential to look at financial crises from both theoretical and practical aspects, as this is an old and recurring phenomenon. However, it is still unknown how to manage their formation. The article aims at assessing the influence of individuals' financial decisions on financial crisis formation. The interface between economic decisions made by individuals and financial crises is assessed using expert evaluation method. The multi-criteria estimation performed using the TOPSIS method to evaluate when individuals make the most irrational decisions. Moreover, finally, economic decisions rationality index is concluded, evaluating when individuals make ridiculous decisions. The rationality index of economic decisions measures the number of irrational decisions during the economic expansion. Economic decisions rationality index divided into three groups: economic factors, financial sector and psychological factors. Assessment of the irrational decisions made during the economic expansion demonstrates that during the first period (2001-2006) the least irrational decisions were made in 2001 and the most in 2004; while during the second period (2010-2017), the least irrational decisions were made in 2011 and the most in 2015. The limitation of the research is that the data is accessible only for the US; hence, the results could differ in other countries.
\end{abstract}

Keywords: financial crisis, multi-criteria decision-making methods (MCDM), technique for order of preference by similarity to ideal solution (TOPSIS), economic decisions rationality index.

JEL Classification: D91, G01.

\section{Introduction}

People's decision-making process is being investigated by researchers working in a wide range of scientific fields, especially in the field of behavioural economics. Scholars have proved that peoples' economic decisions not only have a significant impact on the state of the country's economy but also could be a trigger to a financial crisis. As it is widely known, peoples' decisions are usually based on subjective things, such as feelings, personal beliefs, lack of knowl-

${ }^{\star}$ Corresponding author. E-mail: viktorija.skvarciany@vgtu.lt 
edge in a specific area, which means that a significant part of made decisions is irrational. It is these decisions frequently cause financial crises even if the economy is booming. In other words, financial crises often occur not only due to economic and political factors, but also psychological ones. However, when analysing preventive measures for financial crises, only state-run political, economic and financial sector reforms are mentioned. One can find indicators that show the situation in these areas, but the impact of people decisions on financial crises has been examined fragmentally and needs more in-depth investigation.

Expectations, self-confidence and self-determination drive most people choices during booms (and during downturns the fear). We need to determine the effect of people decisions to manage or reduce the impact on financial crises in the future. The problem is that financial crises are an old phenomenon influenced by many different factors, but it is still unknown how to manage their formation or diminish their consequences. It is evident that when asset values increase and interest rates are low people tend to consume more, increase their investments and borrowings, which further support economic growth (Purica, 2015). Sayim and Rahman (2015) conclude that one of the vital components of financial market returns is investor sentiment, which drives such phenomena like herding, bubbles, and crashes more than market fundamentals. Their research proves that there is a relationship between investor sentiment, volatility, and returns in the stock market. Annicchiarico et al. (2019) state that humans are not entirely rational, which means that their decisions could be subject to errors and psychological biases.

Hence, the current study aims at the determination of the impact of economic decisions made by individuals during the boom on financial crises. The article covers the analysis of the theoretical background of the influence of individuals behaviour on financial crises, defining the main factors that determine the decisions made by individuals during the economic upswing and expressing these factors via appropriate indicators; determination of the effect of factors on individuals' decisions during the economic boom; and finally a compilation of an indicator of economic decisions rationality.

The main body of the article consists of three parts. The theoretical framework is devoted to distinguishing the factors having an impact on people's financial decisions and indicators expressing those factors. The methodology part presents the methods that were used for conducting the research and obtaining the results. The empirical findings section is devoted to showing the main results of the study and is divided into three subsections. The first subsection presents the results of experts' evaluation of people's economic decision influence on the financial crises' appearance; the second subsection presents the multi-criteria assessment of the impact of economic decisions of individuals on financial crises; the third subsection is devoted to economic decisions' rationality index development.

\section{Theoretical framework}

A financial crisis is an old and recurring phenomenon, there are no two identical financial crises, but we can see similarities. It is essential to understand the impact of various factors on the financial crisis as it influences societies, which, in turn, could lead to an economic stagnation (Cristófoli \& García Fronti, 2020). Hence, the analysis of factors could help to 
find the most appropriate crisis prevention. Scholars claim that both internal and external factors can cause financial crises; they can start in both the private and public sectors, can be of different types and scales, change their shape over time, begin to spread faster and be felt beyond national borders (Claessens et al., 2013; Dwumfour \& Addy, 2019; Mamun, 2017; Yurdakul, 2014; Zhang \& Broadstock, 2018). Authors think that financial crises often require immediate and comprehensive policy responses, call for significant changes in the financial sector and fiscal policies, and can necessitate global coordination of policies. So, factors can be very different, occur because of state policy or processes in the private sector, and crises are affected by both the micro and macro environments.

Mishkin (1999) and Hahm and Mishkin (2000) analyse the impact of the asset market on the balance sheet (stock market downturn, unexpected fall in prices, depreciation of national currency), balance sheet problems of financial institutions (bank panic and financial institutions decline), increased uncertainty, increased interest rates, asymmetric information problems and government fiscal imbalances. Allen and Gale (2007) highlight the lack of regulation, uncertainty, the banking crisis, the depreciation of the national currency, liberalism, the sharp fall in asset prices, credit growth, interest growth, and stock market collapse. Azbainis (2013) presents the problem of the wrong choice and unfair behaviour, stock market effect on equity, bank panic, and uncertainty about the future, interest growth, and government fiscal imbalances, irrational expectations, lack of regulation, capitalism system problems, and credit expansion. Claessens et al. (2013) analyse unsuitable macroeconomic policies, credit availability, high capital inflows, balance sheet vulnerability, liberalism, misregulation and oversight, inappropriate interventions. In international finance the financial crisis is expressed in the mass withdrawal of capital from the country, an uncontrolled decline of the national currency exchange rate, an uncontrollable increase of the government and external corporate debt, as well as overdue payments, transfer of systemic risk to the international market and financial markets of other states (Gendron \& Smith-Lacroix, 2015; Weiß et al., 2014). In the area of money circulation, the financial crisis manifests itself in the rapid, unmanaged price increase, which moves into continuing inflation, use of foreign (hard) currency in the domestic market (Purica, 2015). In the field of public finances, the financial crisis expresses in an extreme reduction in the size of international reserves and state stabilisation funds, the emergence of shortages or aggravation of the state budget deficit, rapid decrease of tax collection, reduction of public expenditures financing, an unmanaged increase of domestic public debt (Zhang \& Broadstock, 2018).

Askari et al. (2018) state that the specifics of financial crises are that their reasons often have irrational nature. For example, sudden mass withdrawal of the bank deposits, problems and outer effects in the financial markets, limitation of arbitration operations during a crisis, the emergence of bubbles in the market of assets, credit crises, a sale of assets at reduced prices, etc. Hira (2013) analyse the following causes of the financial crisis, which he calls "deeper": housing, monetary policy, the ideology of deregulation amidst politicisation, globalisation constrains options, faith in mathematical models and underlying psychological currents of asset bubbles. Among other psychological factors, the author singles out the situation with credit cards holders (nearly half of credit card holders do not pay full amount at the end of the months, a lot of them have no idea about the interest rate they pay, do not 
understand compound interest and the principles of its operation), that "Western societies are used to living beyond their means via excessive borrowing", and finally - a lot of people "hardly use" the goods they purchase.

Factors presented by mentioned above authors could be divided into four groups. The first group - factors are resulting from public policies, the second - financial sector factors, the third - reflecting people's choices (psychological factors) and the fourth - factors reflecting changes or disturbances in financial markets leading to a decline in economic activity.

Eichengreen and Wyplosz (1998) believe that all financial crises have warning signs that need to be addressed before the recession, but usually, these sings are noticed too late. People do not learn lessons from previous mistakes. So it is essential to analyse factors causing financial crises to identify appropriate prevention measures. The analysis of various indicators that is related to financial crises shows that there is no one universal system, which determines when the financial crisis will occur. Some authors (Frankel \& Saravelos, 2012; Reinhart \& Rogoff, 2009; Summers, 2000) analyse many different indicators of a country. Such as foreign exchange reserves, real exchange rate, GDP, credit, current account, money supply, imports and exports, inflation, return on equity, real interest rate, debt composition, budget balance, current and long term liabilities, high fiscal deficit, monetary policy liabilities, trading conditions, the political or legal environment, capital flows and external debt.

Swedbank (2018) developed "overheating economic index", which shows the "temperature" of the country's economy. "Overheating economic index" includes annual inflation rate (excluding food, energy, alcohol and tobacco), the share of the current account balance from GBP, unemployment, the wage growth and productivity gap, the difference between credit and nominal GDP growth, the ratio between the average salary and the housing price in the capital city. The total overheating index is computed by calculating the arithmetic mean of all six indicators. Swedbank (2018) "economic overheating index" and its fundamental indicators measure changes in the balance between demand and supply in an economy, helps to identify potential risks in an economy and could help guide the appropriate macroeconomic policy. Irrational expectations can lead to excessive lending, possibly even forming asset price bubbles.

Financial crises can start in a country and widen globally, or a financial crisis in a country can result from the economic downturn of foreign countries. The Czech National Bank (2012) identified early warning indicators, which show the threat of financial crisis. All signs divided into two groups - national indicators and global indicators. There are nine national indicators - housing prices, debts and savings, external balance, capital market situation, banking system situation, monetary policy stance, money and credit, the real economy and foreign debt. Furthermore, there are eight global indicators - global GDP, oil prices, universal credit, global inflation, global FDI inflow, global export prices, terms of trade and global trade. Nowadays, it is imperative to analyse indicators, not only nationally but also globally. The economies of many countries are related. As a result of the onset of the financial crisis, most countries are also affected by globalisation.

According to scientific literature and banks' (commercial and national) researches' analysis (Czech National Bank, 2012; Frankel \& Saravelos, 2012; Reinhart \& Felton, 2009; Summers, 2000; Swedbank, 2018), all mentioned indicators divided into three groups: national 
indicators, financial sector indicators and global indicators. Many different indicators signal the financial crisis and global context must also be observed because a financial crisis can start due to the situation abroad. Comparing the indicators analysed to identify the origins of financial crises and the factors that cause financial crises, even though people's choices and decisions can lead to financial crises, the indicators presented by various authors do not reflect these choices. So financial crises analysis should include more signs, which indicate people's moods and the potential impact of their economic decisions.

When the economy is on the boom, people's decisions can lead to a speculative bubble. Moreover, when a recession begins, a massive withdrawal of deposits from banks can disrupt a well-functioning bank. Factors that cause financial crises also include people choices because the economic decisions have an impact on financial crises before and during the crisis. Petach (2020) analyses the "total amount of outstanding consumer credit and the ratio of real personal consumption expenditures to disposable income" and found out that "the creditsupply shock and financial crisis had distinct impacts on per-capita indebtedness". Ricciardi (2017) investigates group behaviour within the investment decision-making process, drawing on the social sciences (largely social psychology) to consider the topics of "group polarisation and groupthink" aiming to encourage researchers to investigate these important issues as potential origins of historical actions within banking, economics, and finance.

Gerrans et al. (2013) examine individual investors' tolerance towards financial risk related to the 2007-2009 global financial crisis and state that "financial risk tolerance tends to be a reasonably stable attribute in the shorter term but possibly influenced and reshaped by events more gradually over time". Anastasiu (2017) searches the impact of "context effects on the economic decision-making process" during crisis and no-crisis. While Shefrin and Statman (2011) point out that "excessive optimism leads investors to expect unwarranted increases not only in the prices of stocks and other assets, such as houses but also in future short-term (real) interest rates". They conclude that psychology underlies much of our crisis; that "aspirations propelled many renters into houses they could not afford, evoking emotions and cognitive errors that blinded homeowners to risk".

People's financial decisions can depend on their psychology, mood, and financial literacy. Financial behaviour describes how psychological phenomena affect their financial behaviour, how people behave in real financial situations. Financial behaviour is a combination of three different disciplines: psychology, sociology and finance (Arianti, 2018). These three areas are very different and seem to be incompatible, but analysis of different financial decisions presents that psychological and social factors can lead to irrational choices. In economics, rationality means that the individual chooses the most advantageous choice from all available options, that is, evaluates all costs and benefits (Vriend, 1996). So rational economic decision based on calculations that evaluate all alternatives, their costs and benefits. However, often individual choices are driven by other factors. According to De Bondt and Thaler (1994), people's preferences may depend on their overconfidence and the way they present the problem, just as the estimated expected payback. So irrational economic decision not based on calculation and more influenced by the individual mood, intuition or expectations.

Investors often suffer from the syndrome "this time is different" and do not notice any signs of financial crisis threat, and it turns out that each financial crisis surprises investors 
(Gennaioli et al., 2015). Emotions drive investors ignoring warning signs about the financial crisis threat, and they try to earn the most from it. Nevertheless, when prices start to fall, panic and uncertainty about the future increase, more and more investors begin to sell their assets, and the prices drop even faster. During the economic expansion, people's decisions influenced by self-confidence and expectations, and during the recession - fear and uncertainty about the future.

Emotions have a significant impact on various economic and financial decisions. Therefore Akerlof and Shiller (2009) analyse financial crises through human psychology. Authors think that irrational thinking causes financial crises; they suggest that financial crises analysis has to ignore the "rational man" (Akerlof \& Shiller, 2009). Different irrational decisions can be made not only because of emotion but also because of lack of information. Immoral behaviour and asymmetric information also have a significant impact on financial crises. According to Hahm and Mishkin (2000), the financial system cannot be effective due to asymmetric information problems, and that leads to poor choices and moral hazard problems. Often in commercial deals, one side has more information than the counterparty. In financial crises analysis, it is important to include not only economic and financial indicators but also the human factor. Hira (2013) states that individual solutions taken together generate costs for both - the individual and society as a whole. Psychologists stress that "the lack of recognition of these factors" also affects everyone. People "tend to ignore consequences" that are not "direct" and visible, or that seem staggering as a whole.

If people's decisions were always rational, and based on calculations, there would be fewer financial crises, but much of choice is irrational. We can see this when the economy is growing, then wages and employment is rising too, along with expectations and confidence in financial position. So people's decisions during the economic expansion are an essential part of financial crises, as well as a vital aspect for determining appropriate preventive measures the factors determining people's financial decisions and indicators expressing them presented in Table 1.

Table 1. Factors influencing people's financial decisions and indicators expressing (source: created by authors based on Azbainis, 2013; Allen \& Gale, 2007; Frankel \& Saravelos, 2012; Hahm \& Mishkin, 2000; Mishkin, 1999; Reinhart \& Rogoff, 2009; Summers, 2000)

\begin{tabular}{|l|l|}
\hline \multicolumn{1}{|c|}{ Factor } & \multicolumn{1}{c|}{ Indicator } \\
\hline The economic situation of the country & GDP \\
\hline Inflation rate in the country & Inflation \\
\hline Income & Average annual wage \\
\hline The unemployment rate in the country & Unemployment \\
\hline Credit availability & Domestic credit provided by the financial sector \\
\hline Lending interest rate & Lending interest rate \\
\hline Expectations & VIX index \\
\hline $\begin{array}{l}\text { Confidence about one's financial situation in the } \\
\text { future }\end{array}$ & Consumer confidence index (CCI) \\
\hline
\end{tabular}


Factors and indicators presented in Table 1 reflect the country's economic state, activities of financial markets and institutions, and people's behaviour. All elements not only show the country's economic state but also influence people's economic decision making.

\section{Methodology}

The expert evaluation method is employed to assess an interface between economic decisions made by individuals and financial crises. The factors that have an impact on individuals' irrational economic decisions were scored and examined for their convergence using the Kendall coefficient of concordance $W$ method. Let $R_{i j}$ denote the rank of $i$-th alternative ( $i=$ $1, \ldots, n)$ assigned by the $j$-th expert $(j=1, \ldots, k)$. Let $x_{i}$ be the sum of the ranks given to object $i, R_{i}=\sum_{j=1}^{k} R_{i j}$. The Kendall coefficient of concordance $W$ is calculated using the belowpresented formula (Marozzi, 2014):

$$
W=\frac{12 \sum_{i=1}^{n}\left(R_{i}-\bar{R}\right)^{2}}{p^{2}\left(n^{3}-n\right)-p \sum_{k=1}^{m}\left(t_{k}^{3}-t_{k}\right)},
$$

where: $n$ - number of alternatives; $p$ - number of experts; $t_{k}$ - the number of tied ranks in each of $m$ groups of ties.

One of the significance tests of the Kendall coefficient of concordance is Friedman's statistic that is related to $W$ by the following equation (Legendre, 2005; Marozzi, 2014):

$$
\chi^{2}=W p(n-1)
$$

The $\chi^{2}$ has $n-1$ degrees of freedom as $p$ tends to infinity. Hence, the null hypothesis that states that $W=0$ is rejected if $\chi^{2} \geq \chi_{\text {crit. }}^{2}$.

The Kendall coefficient of concordance indicates the level of agreement between the experts, i.e. the more the coefficient closer to 1 , the higher is the level of agreement $(W \in[0 ; 1])$; however, it does not show the level of expertise of the selected experts. The experience is one of the most influential factors for obtaining reliable results. Hence, in the current study, the coefficient of expertise to each of the experts is calculated using the following formulas (Augustinaitis et al., 2009):

$$
\begin{gathered}
K_{j}^{0}=\frac{1}{m} ; \\
x_{i}^{t}=\sum_{j=1}^{m} K_{j}^{t-1} x_{i j} ; \\
\lambda^{t}=\sum_{i=1 i=1}^{n} \sum_{i}^{m} x_{i}^{t} x_{i j} ; \\
K_{j}^{t}=\frac{1}{\lambda^{t}} \sum_{j=1}^{n} x_{j}^{t} x_{i j},
\end{gathered}
$$

where: $K_{j}^{0}$ - the initial coefficient of competence (it is equal for all the experts); $m$ - the number of experts; $x_{i}^{t}$ - group estimates; $K_{j}^{t-1}$ - group estimate when $t=0 ; x_{i j}$ - the value 
assigned for the $i$-th alternative by the $j$-th expert; $\lambda^{t}$ - the sum of elements; $x_{i}^{t}$ - group estimate of the $i$-th alternative ; $K_{j}^{t}$ - the competence coefficient of the $j$-th expert.

Notably, the sum of all experts' coefficient of competence should be equal to 1, i.e. $\sum_{j=1}^{m} K_{j}^{t}=1$. Moreover, the experts appear to be competent, if $\bar{w}-1.96 s \leq K_{i}^{t} \leq \bar{w}+1.96 s$, where $\bar{w}$ stands for the mean and s stands for standard deviation (Baležentis \& Žalimaite, 2011).

After the expert evaluation is completed, the multi-criteria evaluation is conducted. The assessment is done using multi-criteria decision-making method TOPSIS (Technique for Order of Preference by Similarity to Ideal Solution). TOPSIS is used for ranking the alternatives and identifying the most important one (Kraujaliene, 2019). The decision matrix ought to be determined and the weight assigned to each alternative to start the ranking procedure. All the weights are equal in the current study. After the normalised decision matrix $n_{i j}=x_{i j} /\left(\sum_{i=1}^{m} x_{i j}^{2}\right)^{1 / 2}$ is constructed. After normalisation procedure the weighted normalised decision matrix $v_{i j}=w_{j} n_{i j}(i=1, \ldots, m ; j=1, \ldots, n)$ is constructed, where $w_{j}$ stands for the weight of the $j$-th criterion. Since the positive ideal $V^{+}=\left(v_{1}^{+}, v_{2}^{+}, \ldots, v_{n}^{+}\right)=\left(\max _{i} v_{i j} \mid j \in I\right),\left(\min _{i} v_{i j} \mid j \in J\right)$ and negative ideal $V^{-}=\left(v_{1}^{-}, v_{2}^{-}, \ldots, v_{n}^{-}\right)=\left(\min _{i} v_{i j} \mid j \in I\right),\left(\max _{i} v_{i j} \mid j \in J\right)$ solutions are determined. Here $I$ is associated with benefit criteria and $J$ with the cost criteria, $i=1, \ldots, m ; j=1, \ldots, n$. Next, the separation measures from the positive ideal solution $S_{i}^{+}=\sqrt{\sum_{j=1}^{n}\left(v_{i j}-v_{i}^{+}\right)^{2}}(i=1,2, \ldots, m)$ and the negative ideal solution $S_{i}^{-}=\sqrt{\sum_{j=1}^{n}\left(v_{i j}-v_{i}^{-}\right)^{2}}(i=1,2, \ldots, m)$ are calculated. The last step is to calculate the relative closeness to the positive ideal solution $P_{i}=S_{i}^{-} /\left(S_{i}^{-}+S_{i}^{+}\right)$and according to it rank the alternatives.

\section{Empirical findings}

\subsection{Experts' valuation of the impact of economic decisions of individuals on financial crises}

The main criteria for selecting experts was their workplace or experience in investing in particular assets. Requirements for the workplace was experienced in financial institutions of at least two years, and investment experience should have been at least five years. Seven experts participated in the study. More detailed information about them presented in Table 2. Experts selected from different age groups, diverse workplaces and positions and some of the experts work in foreign financial institutions to ensure the representativeness of the sample.

The experts ranked eight factors (see Table 1) that are considered to have an impact on people's irrational economic decisions. They also determined weights for each factor, the sum of the weights of all factor for each expert must be 1 . The most influential factor in irrational decisions of people during the economic expansion is rated at 1 , the least -8 . Factors ranking is presented in Table 3, and the weights of factors in Table 4. 
Table 2. Information on the experts involved in the study

\begin{tabular}{|c|l|c|}
\hline No. & \multicolumn{1}{|c|}{ Occupation } & Experience (years) \\
\hline Exp. 1 & Credit analyst at Investment Bank & 2 \\
\hline Exp. 2 & Managerial positions at the Public Investment Development Agency & 4 \\
\hline Exp. 3 & Administrative positions at Invest Lithuania & 5 \\
\hline Exp. 4 & $\begin{array}{l}\text { Management position at Swedbank Trade Finance Department, } \\
\text { Sales Expert }\end{array}$ & 6 \\
\hline Exp. 5 & The employee at the European Central Bank Statistics Department & 2 \\
\hline Exp. 6 & Investor in real estate (in Lithuania and abroad) and raw materials & 7 \\
\hline Exp. 7 & Chartered Financial Analyst, INVL Asset Management & 9 \\
\hline
\end{tabular}

Table 3. Ranking of factors influencing people financial decisions (source: authors' calculations)

\begin{tabular}{|c|c|c|c|c|c|c|c|c|}
\hline & 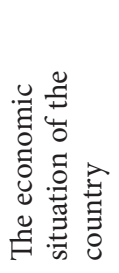 & 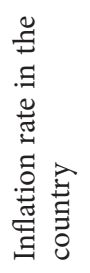 & 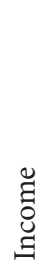 & 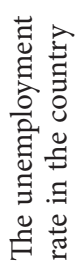 & 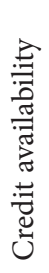 & 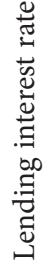 & 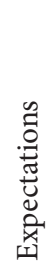 & 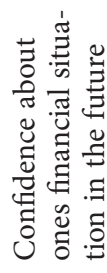 \\
\hline Exp. 1 & 8 & 6 & 2 & 7 & 4 & 5 & 3 & 1 \\
\hline Exp. 2 & 7 & 6 & 5 & 8 & 3 & 4 & 2 & 1 \\
\hline Exp. 3 & 5 & 4 & 1 & 6 & 7 & 8 & 3 & 2 \\
\hline Exp. 4 & 7 & 4 & 2 & 3 & 5 & 6 & 8 & 1 \\
\hline Exp. 5 & 7 & 8 & 1 & 6 & 3 & 4 & 5 & 2 \\
\hline Exp. 6 & 8 & 7 & 2 & 6 & 5 & 4 & 3 & 1 \\
\hline Exp. 7 & 3 & 7 & 1 & 5 & 4 & 6 & 8 & 2 \\
\hline
\end{tabular}

Based on the ranking of factors (see Table 3), Kendall's coefficient of concordance W and $\chi^{2}$ were calculated. Kendall's coefficient of concordance is equal to 0.574 and $\chi^{2}$ to 28.126, which is higher than $\chi_{7,0.05}^{2}=14.067$. Hence, it could be stated that the null hypothesis is rejected and there is an agreement between the experts.

Kendall's coefficient of concordance does not evaluate the competence of experts, so it is required to calculate the expertise coefficient. Hence, based on the rankings, the competency coefficient is calculated for each expert (see Table 4). Calculated expert's coefficient of expertise should be in the interval $0.1359 \leq K_{i}^{t} \leq 0.1498$. Competency coefficients of all experts presented in Table 5.

Table 4. Coefficients of experts' competence (source: authors' calculations)

\begin{tabular}{|l|c|c|c|c|c|c|c|}
\hline & Exp. 1 & Exp. 2 & Exp. 3 & Exp. 4 & Exp. 5 & Exp. 6 & Exp. 7 \\
\hline $\begin{array}{l}\text { Competence } \\
\text { coefficients }\end{array}$ & 0.1471 & 0.1404 & 0.1406 & 0.1400 & 0.1461 & 0.1466 & 0.1393 \\
\hline
\end{tabular}


Estimated competency coefficient of experts should be in interval $0.1359 \leq K_{i}^{t} \leq 0.1498$. So, all experts involved in the study are competent. The survey can be continued because experts' opinion is consistent, and all experts are competent.

\subsection{The multi-criteria evaluation of the impact of economic decisions of individuals on financial crises}

The multi-criteria evaluation performed using the TOPSIS method is used when individuals make the most irrational decisions. Due to the lack of data, the study uses only US macroeconomic data. Factors influencing people financial decisions and the indicators that express them listed in Table 1. The results obtained by the TOPSIS method are presented in the table below (see Table 5).

Table 5. US macroeconomic data, 2001-2006 (source: Federal Reserve Bank of St. Louis, 2020; OECD, 2019; World Bank, 2019a, 2019b, 2019c, 2019d, 2019e)

\begin{tabular}{|l|c|c|c|c|c|c|c|c|}
\hline \multirow{2}{*}{$\begin{array}{c}\text { Direc- } \\
\text { tion }\end{array}$} & $\begin{array}{c}\text { GDP } \\
\text { (current US\$) }\end{array}$ & $\begin{array}{c}\text { Inflation, } \\
\text { consumer } \\
\text { prices } \\
\text { annual } \\
\%)\end{array}$ & $\begin{array}{c}\text { Average } \\
\text { annual } \\
\text { wage }\end{array}$ & $\begin{array}{c}\text { Unem- } \\
\text { ploy- } \\
\text { ment, } \\
\text { total } \\
\text { \% of } \\
\text { the total } \\
\text { labour } \\
\text { force) }\end{array}$ & $\begin{array}{c}\text { Domestic } \\
\text { credit } \\
\text { provided } \\
\text { by the } \\
\text { financial } \\
\text { sector (\% } \\
\text { of GDP) }\end{array}$ & $\begin{array}{c}\text { Lending } \\
\text { interest } \\
\text { rate }\end{array}$ & VIX & $\begin{array}{c}\text { Consumer } \\
\text { confidence } \\
\text { index } \\
\text { (CCI) }\end{array}$ \\
\cline { 2 - 10 } & $\max$ & $\min$ & $\max$ & $\min$ & $\max$ & $\min$ & $\min$ & $\max$ \\
\hline 2001 & $1.05818 \times 10^{13}$ & 2.826 & 40049 & 4.73 & 199.36 & 6.9217 & 25.75 & 100.3025 \\
\hline 2002 & $1.09364 \times 10^{13}$ & 1.586 & 40896 & 5.78 & 192.53 & 4.6750 & 27.29 & 100.2943 \\
\hline 2003 & $1.14582 \times 10^{13}$ & 2.270 & 42201 & 5.99 & 207.54 & 4.1225 & 21.98 & 100.1405 \\
\hline 2004 & $1.22137 \times 10^{13}$ & 2.677 & 44057 & 5.53 & 214.00 & 4.3400 & 15.48 & 100.9385 \\
\hline 2005 & $1.30366 \times 10^{13}$ & 3.393 & 45364 & 5.08 & 217.29 & 6.1892 & 12.81 & 100.2014 \\
\hline 2006 & $1.38146 \times 10^{13}$ & 3.226 & 47337 & 4.62 & 227.02 & 7.9575 & 12.81 & 100.0724 \\
\hline
\end{tabular}

Multi-criteria evaluation completed for two periods of economic expansion 2001-2006 (Table 6) and 2010-2017 (Table 7). Table 5 and Table 6 present primary data of indicators and determine indicators directions. According to the submitted data, four indicators are maximising, the other four minimising. In the multi-criteria evaluation by TOPSIS, all indicators should be one-way, that is, maximised according.

Using the US data presented in Tables 5-6, the ranking procedure using the TOPSIS method was performed. The values of relative closeness to the positive ideal solution $P_{i}$ are presented in Tables 7 and 8.

According to the results presented in Table 7, the most irrational decisions were made in 2004 and the least - in 2001. The results for the second analysed period are presented in the following. 
Table 6. US macroeconomic data, 2010-2017 (source: Federal Reserve Bank of St. Louis, 2020; OECD, 2019; World Bank, 2019a, 2019b, 2019c, 2019d, 2019e)

\begin{tabular}{|c|c|c|c|c|c|c|c|c|}
\hline & $\begin{array}{c}\text { GDP (current } \\
\text { US\$) } \\
\text { tion }\end{array}$ & $\begin{array}{c}\text { Inflation, } \\
\text { consumer } \\
\text { prices } \\
\text { (annual \%) }\end{array}$ & $\begin{array}{c}\text { Average } \\
\text { annual } \\
\text { wage }\end{array}$ & $\begin{array}{c}\text { Unem- } \\
\text { ployment, } \\
\text { total (\% } \\
\text { of total } \\
\text { labour } \\
\text { force) }\end{array}$ & $\begin{array}{c}\text { Domestic } \\
\text { credit } \\
\text { provided } \\
\text { by financial } \\
\text { sector } \\
\text { (\% of } \\
\text { GDP) }\end{array}$ & $\begin{array}{c}\text { Lending } \\
\text { interest } \\
\text { rate }\end{array}$ & VIX & $\begin{array}{c}\text { Consumer } \\
\text { confidence } \\
\text { index } \\
\text { (CCI) }\end{array}$ \\
\cline { 2 - 11 } & $\max$ & $\min$ & $\max$ & $\min$ & $\max$ & $\min$ & $\min$ & $\max$ \\
\hline 2010 & $1.49921 \times 10^{13}$ & 1.640 & 52593 & 9.63 & 224.75 & 3.2500 & 22.55 & 98.2649 \\
\hline 2011 & $1.55426 \times 10^{13}$ & 3.157 & 54003 & 8.95 & 224.81 & 3.2500 & 24.20 & 97.7644 \\
\hline 2012 & $1.6197 \times 10^{13}$ & 2.069 & 55480 & 8.07 & 227.19 & 3.2500 & 17.80 & 98.8019 \\
\hline 2013 & $1.67848 \times 10^{13}$ & 1.465 & 55964 & 7.38 & 239.07 & 3.2500 & 14.23 & 99.1221 \\
\hline 2014 & $1.75217 \times 10^{13}$ & 1.622 & 57614 & 6.17 & 242.01 & 3.2500 & 14.18 & 99.6986 \\
\hline 2015 & $1.82193 \times 10^{13}$ & 0.119 & 59176 & 5.28 & 235.49 & 3.2600 & 16.67 & 100.6948 \\
\hline 2016 & $1.87072 \times 10^{13}$ & 1.262 & 59858 & 4.87 & 240.81 & 3.5117 & 15.83 & 100.5818 \\
\hline 2017 & $1.94854 \times 10^{13}$ & 2.130 & 61476 & 4.36 & 249.694 & 3.8967 & 11.09 & 101.1521 \\
\hline
\end{tabular}

Table 7. Irrational decision making during 2001-2006 (source: authors' calculations)

\begin{tabular}{|l|c|c|c|c|c|c|}
\hline & 2001 & 2002 & 2003 & 2004 & 2005 & 2006 \\
\hline$P_{i}$ & 0.186 & 0.487 & 0.466 & 0.553 & 0.508 & 0.498 \\
\hline Place & 6 & 4 & 5 & 1 & 2 & 3 \\
\hline
\end{tabular}

Table 8. Irrational decision making during 2010-2017 (source: authors' calculations)

\begin{tabular}{|l|c|c|c|c|c|c|c|c|}
\hline & 2010 & 2011 & 2012 & 2013 & 2014 & 2015 & 2016 & 2017 \\
\hline$P_{i}$ & 0.072 & 0.065 & 0.124 & 0.201 & 0.221 & 0.808 & 0.244 & 0.329 \\
\hline Place & 7 & 8 & 6 & 5 & 4 & 1 & 3 & 2 \\
\hline
\end{tabular}

The most irrational decisions were made in 2015 and the least in 2011. The multi-criteria evaluation made by the TOPSIS method showed that fewer irrational decisions were made after the financial crisis, and more irrational decisions were made when the economy is growing.

The obtained results show that just after crises (dot.com in 2001-2002 and global financial in 2007-2008) people are precautious and do not entangle into incautious decisions. While when the economic situation is improving people became more adventurous and started overtaking more risky decisions. Now we can state that the most irrational financial decisions people make a few years before the crisis. Although the future financial crisis is not related directly to financial reasons, it is clear that 2020 will go down into the history as the year of one more economic crisis, and, probably more profound than the previous one (2007-2008). 


\subsection{Rationality index of economic decisions}

Economic decisions rationality index is concluded from multi-criteria evaluation using the TOPSIS method, evaluating when individuals make the most irrational decisions. The rationality index of economic decisions measures the number of irrational decisions during the economic expansion.

Economic decisions rationality index is divided into three groups (Figure 1): economic factors, financial sector factors and psychological factors. Economic factors group consist of four indicators: GDP (current US \$), inflation, consumer prices (annual \%), unemployment, total (\% of the total labour force) and yearly average wages (US \$). There are two financial sector factors - lending interest rate and credit availability, expressed by domestic credit provided by the financial sector (\% of GDP). The index includes two psychological factors expectations expressed by the VIX index and confidence about the future finance represented by the consumer confidence index.

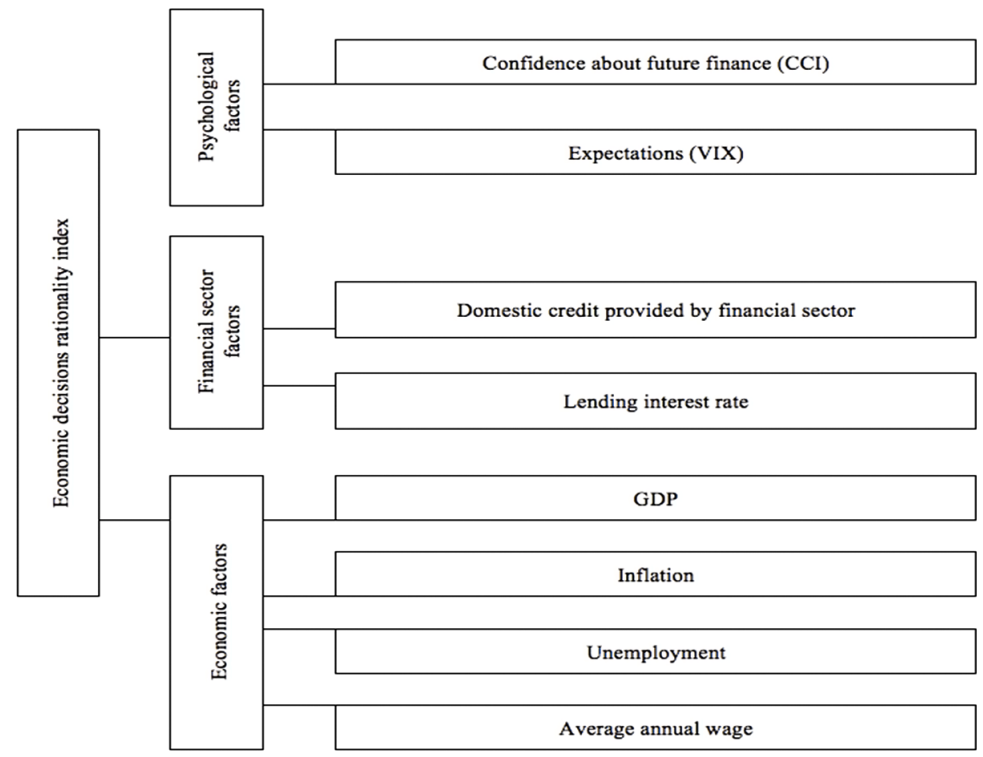

Figure 1. Components of economic decisions rationality index (source: created by authors)

Figure 2 and Figure 3 present economic decisions rationality index in two economic expansion periods, 2001-2006 and 2010-2017. Index values range from 0 to 1 . There are fewer irrational decisions made if the value is closer to 1 . A value close to 1 means that many irrational decisions are made.

It can be seen that in the period 2001-2006, the most irrational decisions were made in 2004, while the least irrational decisions were made in 2001 (Figure 2). In the first analysed period, the most significant change has been seen from 2001 until 2002, in 2001, the value of the index was 0,18572 , and in $2002-0.48688$. Since 2002 until 2003, the number of irrational decisions has fallen slightly; the value of the index was 0.46562. 2004 was the year when the highest value of the index reached - 0.55330; from 2004 to 2006, the number of irrational decisions decreased: in 2005, value 0.50755 , and $2006-0.49823$. 


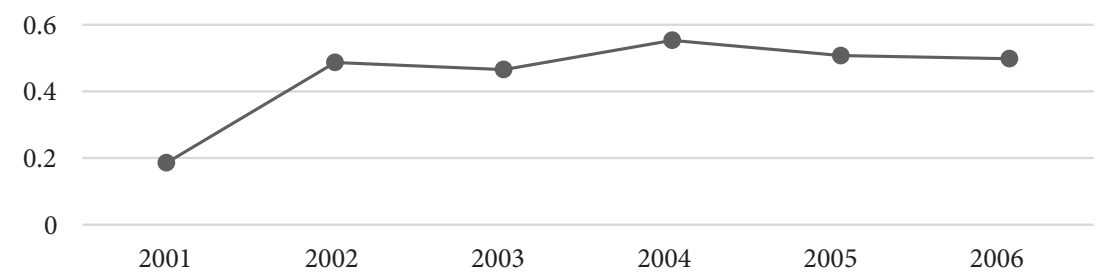

Figure 2. Economic decisions rationality index during 2001-2006 (source: authors' calculations)

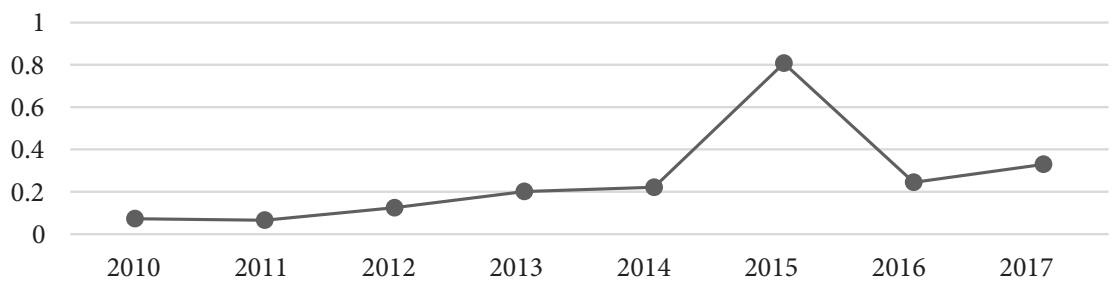

Figure 3. Economic decisions rationality index during 2010-2017 (source: authors' calculations)

During 2010-2017 period (Figure 3) most irrational decisions were made in 2015, the most significant amount is seen in the period from 2014 until 2015. Since 2010 until 2011, the number of irrational decisions fell; the value of the index in 2010 was 0.072167 and in $2011-0.06493$. However, from 2011 until 2015, the number of irrational decisions was always growing; the value of the index in 2014 was 0.22061 , and the highest value reached in 2015 (0.80817). As of from 2015 until 2016, the value of irrational decisions dropped to 0.24425 , but in 2017 the number of irrational decisions increased to 0.32901 .

The rationality index of economic decisions measures only irrational decisions made during the economic expansion because, in this period, economic decisions are often driven by self-confidence, expectations and how individuals feel about future finance. And in the economic recession, irrational decisions are driven by other factors.

Analysing rationality of economic decisions in the US after these two financial crises show that in the first period (Figure 2) more irrational decisions were made after the crisis than in the second period (Figure 3). Because consequences after Dot.com financial crisis were not as severe as of the global economic crisis, individuals began faster to make more irrational economic decisions. So when people are more confident, they save less for the future, consumerism rises, expectations increase and more irrational decisions are made.

\section{Conclusions}

Managing financial crises and their formation requires analysis of the impact of people's economic decisions on financial crises. The identified factors that affect the people's economic decisions expressed in the following indicators: the economic situation of the country - GDP (current US \$), the inflation rate in the country - inflation, consumer prices (annual \%), income - annual average wages (US \$), the unemployment rate in the country - unemployment, total (\% of the total labour force), lending interest rate, credit availability - domestic 
credit provided by financial sector (\% of GDP), expectations - VIX index and confidence about future finance - consumer confidence index. All factors not only show the state of the economy of the country but also influence people's economic decision making.

The study showed that experts' opinion was consistent, and all experts are competent. Experts ranked eight factors that have an impact on people's irrational economic decisions, and they also determined weights for each factor, according to factors ranking the most effect on people's irrational decisions is the confidence about future finance. In second place was income, third - expectations, fourth - credit availability, fifth - lending interest rate, sixth - unemployment, seventh - inflation and eight - economic situation of the country. Experts think that psychological and financial factors determine most irrational decisions during economic expansion.

Evaluation of the irrational decisions made during the economic expansion performed using the TOPSIS method during two periods 2001-2006 and 2010-2017. During the first period of 2001-2006, the least irrational decisions were made in 2001 and the most in 2004. In the second period 2010-2017, the least irrational decisions were made in 2011 and the most in 2015. Results show that people are discreet in their financial decisions while their memory "alive", but after a few years, they forget recent (unfavourable) experiences and overtake riskier financial decisions again due to rising expectations.

Economic decisions rationality index is developed from multi-criteria evaluation using the TOPSIS method, evaluating when individuals make the most irrational decisions. Economic decisions rationality index is divided into three groups: economic factors (GDP, inflation, unemployment, annual average wages), financial sector factors (lending interest rate, domestic credit provided by financial sector) and psychological factors (VIX index and consumer confidence index).

The limitation of the research is that the data is accessible only for the US; hence, the results could differ in other countries. Based on that, future research will focus on the EU countries in order to find the relationship between people's economic decisions and financial crises occurrence. This will help not only to find the linkage but also will contribute to the prediction of future financial crises.

\section{References}

Akerlof, G. A., \& Shiller, R. J. (2009). Animal spirits: how human psychology drives the economy, and why it matters for global capitalism. Princeton University Press. https://bit.ly/34c6cLX

Allen, F., \& Gale, D. (2007). Understanding financial crises. Oxford University Press. https://doi.org/10.4337/9781785366468

Anastasiu, D. M. (2017). Behavioural finance: Providing a Helping hand in understanding individuals financial behavioural. International Journal of Academic Research in Accounting, Finance and Management Sciences, 7(4), 128-133. https://doi.org/10.6007/IJARAFMS/v7-i4/3443

Annicchiarico, B., Surricchio, S., \& Waldmann, R. J. (2019). A behavioral model of the credit cycle. Journal of Economic Behavior \& Organization, 166, 53-83. https://doi.org/10.1016/j.jebo.2019.09.010

Arianti, B. F. (2018). The influence of financial literacy, financial behavior and income on investment decision. Economics and Accounting Journal, 1(1), 1-10. 
Askari, M., Shirazi, H., \& Aghababaei Samani, K. (2018). Dynamics of financial crises in the world trade network. Physica A: Statistical Mechanics and its Applications, 501, 164-169.

https://doi.org/10.1016/j.physa.2018.02.153

Augustinaitis, A., Rudzkienè, V., Petrauskas, R. A., Dagyte, I., Martinaitytė, E., Leichteris, E., Malinauskiene, E., Višnevska, V., \& Žalioniene, I. (2009). Lietuvos e. valdžios gairès: ateities j̇žvalgu tyrimas. Mykolas Romeris University. https://bit.ly/2W7eL7k

Azbainis, V. (2013). Finansų krizių teorija. Iš I. Mačerinskienè (Sud.), Finansų rinkų jžvalgos (p. 402450). Mykolo Romerio universitetas.

Baležentis, A., \& Žalimaitè, M. (2011). Ekspertinių vertinimų taikymas inovacijų plètros veiksnių analizejje: Lietuvos inovatyvių įmonių vertinimas. Management Theory and Studies for Rural Business and Infrastructure Development, 3(27), 23-31. http://mts.asu.lt/mtsrbid/article/viewFile/269/298

Claessens, S., Kose, M. A., Laeven, L., \& Valencia, F. (2013). Understanding Financial crises: Causes, consequences, and policy responses. (Working Paper No. 1301). Koç University-TÜSİAD Economic Research Forum (ERF), Istanbul. https://doi.org/10.2139/ssrn.2295199

Cristófoli, M. E., \& García Fronti, J. (2020). Stress Test Bancarios: selección de indicadores claves para la estabilidad financiera. Cuadernos de Economía, 43(121), 63-78.

https://doi.org/10.32826/cude.v43i121.116

Czech National Bank. (2012). Financial Stability Report 2012. Central Bank of Bahrain.

De Bondt, W. F., \& Thaler, R. (1994). Financial decision-making in markets and firms: A behavioral perspective. National Bureau of Economic Research. https://doi.org/10.3386/w4777

Dwumfour, R. A., \& Addy, N. A. (2019). Interest rate and exchange rate exposure of portfolio stock returns: Does the financial crisis matter? Journal of African Business, 20(3), 339-357. https://doi.org/10.1080/15228916.2019.1583977

Eichengreen, B., \& Wyplosz, C. (1998). The Stability Pact: more than a minor nuisance? Economic Policy, 13(26), 65-113. https://doi.org/10.1111/1468-0327.00029

Federal Reserve Bank of St. Louis. (2020). CBOE Volatility Index: VIX (VIXCLS). https://fred.stlouisfed.org/series/VIXCLS

Frankel, J., \& Saravelos, G. (2012). Can leading indicators assess country vulnerability? Evidence from the 2008-09 global financial crisis. Journal of International Economics, 87(2), 216-231. https://doi.org/10.1016/j.jinteco.2011.12.009

Gendron, Y., \& Smith-Lacroix, J.-H. (2015). The global financial crisis: Essay on the possibility of substantive change in the discipline of finance. Critical Perspectives on Accounting, 30, 83-101. https://doi.org/10.1016/j.cpa.2013.09.002

Gennaioli, N., Shleifer, A., \& Vishny, R. (2015). Neglected risks: The psychology of financial crises (NBER Working Paper No. 20875). National Bureau of Economic Research. https://doi.org/10.3386/w20875

Gerrans, P., Faff, R., \& Hartnett, N. (2013). Individual financial risk tolerance and the global financial crisis. Accounting \& Finance, 55(1), 165-185. https://doi.org/10.1111/acfi.12053

Hahm, J.-H., \& Mishkin, F. S. (2000). The Korean financial crisis: An asymmetric information perspective. Emerging Markets Review, 1(1), 21-52. https://doi.org/10.1016/S1566-0141(00)00003-0

Hira, A. (2013). Irrational exuberance: An evolutionary perspective on the underlying causes of the financial crisis. Intereconomics, 48(2), 116-123. https://doi.org/10.1007/s10272-013-0452-0

Kraujaliene, L. (2019). Comparative analysis of multicriteria decision-making methods evaluating the efficiency of technology transfer. Business, Management and Education, 17, 72-93. https://doi.org/10.3846/bme.2019.11014

Legendre, P. (2005). Species associations: The Kendall coefficient of concordance revisited. Journal of Agricultural, Biological, and Environmental Statistics, 10(2), 226-245.

https://doi.org/10.1198/108571105X46642 
Mamun, A. (2017). An investigation of the factors causing financial crisis: Lessons from recent overwhelming episodes. Journal of Academic Research in Economics (JARE), 9(1), 7-18.

Marozzi, M. (2014). Testing for concordance between several criteria. Journal of Statistical Computation and Simulation, 84(9), 1843-1850. https://doi.org/10.1080/00949655.2013.766189

Mishkin, F. S. (1999). Global financial instability: Framework, events, issues. Journal of Economic Perspectives, 13(4), 3-20. https://doi.org/10.1257/jep.13.4.3

OECD. (2019). Average annual wages OECD. https://bit.ly/3eUeNYG

Petach, L. (2020). Local financialisation, household debt, and the great recession. Papers in Regional Science. https://doi.org/10.1111/pirs. 12505

Purica, I. (2015). Evolution of financial crises. In Nonlinear Dynamics of Financial Crises (pp. 9-21). Elsevier. https://doi.org/10.1016/B978-0-12-803275-6.00002-1

Reinhart, C. M., \& Felton, A. (2009). The first global financial crisis of the 21st century, Part II: Introduction. Centre for Economic Policy Research. www.cepr.org

Reinhart, C. M., \& Rogoff, K. S. (2009). The aftermath of financial crises. American Economic Review, 99(2), 466-472. https://doi.org/10.1257/aer.99.2.466

Ricciardi, V. (2017). The role of group psychology in behavioural finance: A research starting point for banking, economic, and financial historians. Decision Taking, Confidence and Risk Management in Banks from Early Modernity to the 20th Century (pp. 269-292). Springer International Publishing. https://doi.org/10.1007/978-3-319-42076-9_12

Sayim, M., \& Rahman, H. (2015). The relationship between individual investor sentiment, stock return and volatility. International Journal of Emerging Markets, 10(3), 504-520.

https://doi.org/10.1108/IJoEM-07-2012-0060

Shefrin, H., \& Statman, M. (2011). Behavioral finance in the financial crisis: market efficiency, Minsky, and Keynes.

Summers, L. H. (2000). International financial crises: Causes, prevention, and cures. American Economic Review, 90(2), 1-16. https://doi.org/10.1257/aer.90.2.1

Swedbank. (2018). Rating. https://www.swedbank.com/investor-relations/debt-investor/rating/

Vriend, N. J. (1996). Rational behavior and economic theory. Journal of Economic Behavior and Organization (T. 29). https://doi.org/10.1016/0167-2681(95)00063-1

Weiß, G. N. F., Bostandzic, D., \& Neumann, S. (2014). What factors drive systemic risk during international financial crises? Journal of Banking \& Finance, 41, 78-96. https://doi.org/10.1016/j.jbankfin.2014.01.001

World Bank. (2019a). Domestic credit Provided by Financial Sector (\% of GDP). World Bank. https://bit.ly/2yTjhOY

World Bank. (2019b). GDP (current US\$) | Data. https://bit.ly/3bLmYVd

World Bank. (2019c). Inflation, consumer prices (annual \%) | Data. https://bit.ly/2YcIEWh

World Bank. (2019d). Lending interest rate (\%). World Bank Development Database. https://bit.ly/2y6hZQu

World Bank. (2019e). Unemployment, total (\% of total labor force). https://bit.ly/2xWRVaA

Yurdakul, F. (2014). Factors that trigger financial crises: The case of Turkey. Procedia-Social and Behavioral Sciences, 109, 896-901. https://doi.org/10.1016/j.sbspro.2013.12.561

Zhang, D., \& Broadstock, D. C. (2018). Global financial crisis and rising connectedness in the international commodity markets. International Review of Financial Analysis.

https://doi.org/10.1016/j.irfa.2018.08.003 